\title{
Evaluation of Cerebral Perfusion Deficit in Stroke Patients Using New Transcranial Contrast Imaging CPSTM Technology Preliminary Results
}

\author{
E. Bartels ${ }^{1}$ \\ S. Henning ${ }^{1}$ \\ A. Wellmer ${ }^{2}$ \\ M. Giraldo-Velásquez ${ }^{2}$ \\ P. Kermer ${ }^{2}$
}

\section{Zusammenfassung}

Ziel: Mithilfe der kontrastverstärkten transkraniellen B-Bild-Sonographie ist es möglich, zerebrale Perfusion zu untersuchen. Diese Technik hat jedoch noch methodische Einschränkungen. Das Ziel der vorliegenden Studie ist es, die Darstellbarkeit des zerebralen Perfusionsdefizits nach Applikation des Ultraschallkontrastmittels SonoVue ${ }^{\mathrm{TM}}$ mithilfe einer neuen kontrastmittelspezifischen Software bei Patienten mit akuter zerebraler Ischämie zu untersuchen. Methode: Zehn Personen (6 Schlaganfallpatienten und 4 gesunde Probanden) wurden transkraniell duplexsonographisch nach Bolusapplikation des Ultraschallkontrastmittels SonoVue ${ }^{\mathrm{TM}}$ untersucht. Die transkranielle Untersuchung wurde mit dem Gerät Siemens/Acuson Sequoia 512 mit der Methode „transient response harmonic grey scale imaging with refill kinetics“ durchgeführt. Das Sequoia-Ultraschallgerät wurde mit der neuen kontrastmittelspezifischen Software „Cadence ${ }^{\mathrm{TM}}$ contrast pulse sequencing technology“ (CPS) ausgestattet. Getriggerte Ableitung mit einem mechanischen Index (MI) von 1,1 sowie kontinuierliche Registrierung mit einem MI von 0,28 wurden für die Untersuchung der zerebralen Perfusion in verschiedenen Gehirnregionen verwendet. Die sonographisch dargestellten hypoperfundierten Areale wurden mit den kernspintomographischen Befunden verglichen. Ergebnisse: Das kontrastverstärkte Signal konnte in den Kapillaren des Gehirnparenchyms in der ipsi- und kontralateralen Hemisphäre bis zu der kontralateralen Schädelkalotte bei allen Probanden registriert werden. Bei allen Schlaganfallpatienten konnte mithilfe der getriggerten Ableitung ipsilateral ein Per-

\section{Abstract}

Background and Purpose: Contrast-enhanced transcranial duplex sonography can be used to examine cerebral perfusion. This technique, however, is still faced with methodological problems. The aim of the present study is to evaluate cerebral perfusion deficit after administration of the contrast agent SonoVue ${ }^{\mathrm{TM}}$ in acute stroke patients using new contrast imaging software. Methods: Ten subjects (6 male stroke patients and 4 healthy volunteers), were examined using transcranial duplex sonography (Acuson Sequoia 512 Ultrasound System) after a bolus injection of the contrast agent SonoVue ${ }^{\mathrm{TM}}$. The transcranial examination was performed using transient response harmonic grey scale imaging with refill kinetics. The Sequoia ultrasonographic system was equipped with a new contrast harmonic imaging software "Cadence ${ }^{\mathrm{TM}}$ contrast pulse sequencing technology" (CPS). Triggered images with the mechanical index (MI) at 1.1 as well as continuous registration with MI at 0.28 were used for the evaluation of time intensity curves in several regions of interest. The sonographically imaged hypoperfused areas were compared with findings from MR imaging. Results: In all healthy volunteers, the contrast-enhanced signal could be recognized well in the ipsi- and also in the contralateral hemisphere up to the skull crown. In stroke patients, the perfusion deficit in the area of the MCA could be detected ipsilaterally in all subjects using triggered registration. Additionally, the area of MCA infarction could also be visualized in two patients using contralateral insonation. The low MI continuous imaging was successful in three patients. For all patients, the ischaemic region corresponded well in shape

affiliation

${ }^{1}$ Department of Clinical Neurophysiology, Georg-August-University Göttingen, Germany

2 Department of Neurology, Georg-August-University Göttingen, Germany

correspondence

Eva Bartels MD, PhD - Department of Clinical Neurophysiology, Georg-August-University Göttingen · RobertKoch-Str. 40 • 37075 Göttingen, Germany · Tel.: ++ 49/89/2 97-2 16 · Fax: ++ 49/89/2421-7799 .

E-mail: Bartels.Eva@t-online.de

received: 9.3.2005 - accepted: 22.8 .2005

bibliography

Ultraschall in Med 2005; 26: 478 - 486 c Georg Thieme Verlag KG Stuttgart · New York

DOI 10.1055/s-2005-858765 • Published online 2005

ISSN 0172-4614 
fusionsdefizit im Stromgebiet der A. cerebri media dargestellt werden. Bei zwei Patienten wurde zusätzlich das hypoperfundierte Stromgebiet der A. cerebri media auch bei der kontralateralen Beschallung identifiziert. Die kontinuierliche Darstellung mithilfe eines niedrigen MI-Indexes war erfolgreich bei drei Patienten. Bei allen Patienten stimmte die hypoperfundierte Region bezüglich der Größe und der Form mit den kernspintomographischen Befunden überein. Schlussfolgerung: Die CPS-Technologie erleichtert die sonographische Untersuchung der Perfusion in der Mikrozirkulation des Gehirnparenchyms und ermöglicht die Darstellung des zerebralen Perfusionsdefizits bei Patienten mit zerebraler Ischämie. Weitere Studien bei einem größeren Patientenkollektiv sind notwendig, um die Darstellung des zerebralen Perfusionsdefizits zu optimieren.

\section{Schlüisselwörter}

Transkranielle Duplex-Sonographie · zerebrale Perfusion · Kontrastmittel · Schlaganfall · Infarkt im Gebiet der A. cerebri media . native tissue harmonic imaging and size with the findings from MR imaging. Conclusions: CPS enhances the possibility of perfusion-imaging in cerebral microcirculation and of perfusion-deficit-imaging in patients with cerebral ischaemia. Further studies with a larger number of patients should be carried out to improve this method.

\section{Key words}

Transcranial duplex ultrasonography · cerebral perfusion · contrast media $\cdot$ stroke $\cdot$ middle cerebral artery infarction $\cdot$ native tissue harmonic imaging

\section{Introduction}

Contrast harmonic imaging is a new sonographic technique which permits the evaluation of tissue perfusion after administration of an ultrasound contrast agent. Suitable for this purpose are the second-generation contrast media such as SonoVue ${ }^{\mathrm{TM}}$, constituted of gas microbubbles with a high resistance to pressure permitting them to reach the capillaries of normal or pathological tissue [1, 2]. While microcirculation and organ perfusion of organs like liver, kidney and myocardium [3] were studied first with this technique, several reports were recently published on the imaging of cerebral perfusion [4-7]. The diagnostic value of this method could also be demonstrated in pathological conditions, e. g. in patients with acute hemispheric stroke $[8,9]$.

In the therapy of acute stroke, an early assessment of the hypoperfused area and the quickest possible treatment and reperfusion of the ischaemic deficit is necessary for an optimum clinical outcome. The size of the ischaemic area plays an important role in the prognosis. With cranial computed tomography, the early ischaemic signs may only be visible several hours after the onset of the acute symptoms. For this reason, imaging of the hypoperfused region is preferably performed by magnetic resonance imaging techniques. Using perfusion- and diffusion-weighted MRI (PWI, DWI), the permanently damaged tissue as shown in DWI can be distinguished from the potentially salvageable tissue (following the so-called "mismatch theory" within minutes to hours after onset of the first symptoms [10]). However, MRI examination is still not widely accessible in the early management of stroke. Therefore, ultrasound techniques could be considered as a possible diagnostic alternative for the early visualisation of the ischaemic area. The main advantage in comparison to the MRI techniques is the bed-side application and the real-time results of the sonographic examination.

Imaging of cerebral perfusion, however, is limited because of methodological problems at the present time, especially in cases where the temporal bone window for insonation is not suitable
$[11,12]$. To learn more about cerebral perfusion sonography (and avoiding the temporal bone problem), our group recently performed a study on the contrast imaging of cerebral perfusion deficits in acute stroke patients following decompressive craniectomy [13]. Besides anatomical difficulties, cerebral perfusion sonography is still in an experimental stage because it is faced with considerable technical problems, as will be discussed later.

Utilising our experience from the previous report, in this study we evaluated the feasibility of analysing cerebral perfusion deficits using a new contrast imaging technology - Cadence ${ }^{\mathrm{TM}}$ contrast pulse sequencing technology (CPS) - in addition to the contrast agent SonoVue ${ }^{\mathrm{TM}}$ for the evaluation of cerebral perfusion. To our knowledge, this is the first report in the literature on the use of CPS in particular in combination with a contrast agent in transcranial imaging.

\section{Subjects and Methods}

\section{Subjects}

In the present study, ten subjects (6 male stroke patients, aged 54 to 71 years, mean age 61.5 years and 4 healthy volunteers, 2 men and 2 women, aged 23 to 35 years, mean age 28.7 years) were examined with contrast-enhanced transcranial duplex sonography using CPS.

Two patients suffered an ischaemic stroke in the middle cerebral artery (MCA) territory, one patient had an infarction in the MCA and anterior cerebral artery (ACA) territory, one in the MCA and posterior cerebral artery (PCA) territory, another in the MCA, ACA and PCA territory, and the last patient suffered a recent infarction in the MCA territory and an old infarction in the MCA territory of the contralateral side. MR imaging was done for all patients and taken as reference. As the equipment was at our disposal only for a relatively short time $(2 \times 2$ days $)$, we selected stroke patients for the examination who had been admitted to the hospital within the last 24-48 hours. The onset of stroke in these patients had 
occurred between 1-4 days prior to admission. The examiners were blinded with regard to the location and clinical history of the ischaemia as well as to the clinical and radiological report.

The study complied with the Declaration of Helsinki in its revised form and with the Guidelines for Good Clinical Practice, and was approved by our local ethics committee. All subjects gave written informed consent to the study. The initial examination of the volunteers consisted of taking their clinical history, blood pressure, and body temperature, and performing a physical examination. Inclusion criteria were normal extra- and intracranial ultrasonographic findings using cw-Doppler-sonography, conventional transcranial Doppler-sonography and extra- and transcranial colour-coded duplex ultrasonography. Exclusion criteria in the control group were a history of cerebrovascular disease, pregnancy or lactation, previous allergic reactions, and substance or alcohol abuse. Except for cerebrovascular disease, these criteria applied to the patient group as well.

\section{Ultrasound system}

The transcranial examination was performed with an Acuson Seqouia 512 Ultrasound System (Siemens Medical Solutions, Nürnberg, Germany) equipped with a 2-4 MHz phased array transducer using the contrast harmonic imaging software based on single-pulse transmission technology. With this technology, a single pulse packet is transmitted along the line of sight. The returning signal of this pulse packet is registered and a single pulse of ultrasound is then transmitted along the next consecutive line of sight. The phase of this ultrasound pulse is inverted in comparison to the previous one. The region of overlap along the two lines of sight is the region in which returning signals are added so that the linear signals from tissue are cancelled out, while the nonlinear signals from microbubbles are amplified [14].

The Sequoia ultrasonographic system was additionally equipped with the latest contrast harmonic imaging software - Cadence ${ }^{\mathrm{TM}}$ contrast pulse sequencing technology, which has been shown to be of great value when studying perfusion deficits in the liver or myocardium. The study was carried out using transient response harmonic grey scale imaging (TRI) with refill kinetics as described by Postert and by Seidel $[4,5,15]$. For this purpose, triggered images with pulsing intervals of $1000 \mathrm{~ms}$ were performed by the trigger integrated in the ultrasound system. In two healthy volunteers and in two patients, an examination with triggered images with pulsing intervals of $500 \mathrm{~ms}$ was also carried out. Additionally, a continuous registration was performed for all subjects. The mechanical index was set at 1.1 for the triggered registration and at 0.28 for the continuous registration and remained constant during the session.

\section{Ultrasound contrast agent}

We used the contrast agent SonoVue ${ }^{\mathrm{TM}}$ (Bracco/Altana Pharma), which is commercially available and approved for cerebrovascular examination by the German authorities. This substance was administered as a slow bolus injection via an intravenous catheter placed in the antecubital vein followed by a flush of $5 \mathrm{ml}$ isotonic saline [1]. In both groups (patients and volunteers), $5.0 \mathrm{ml}$ of SonoVue ${ }^{\mathrm{TM}}$ were administered to each person in two portions $(2 \times 2.5 \mathrm{ml})$. The interval between dose applications was at least
10 minutes, or until total disappearance of the contrast effect from the previous administration.

\section{Examination technique}

The examination was performed in the ultrasound laboratory. The examiner placed the transducer on the temporal bone, while an assistant injected the contrast agent, and then adjusted and optimised the parameters of the ultrasound system. Transmitting power setting and gain were optimised for each patient at the beginning of the examination and kept constant. Imaging of the intracranial structures was performed following the same protocol as in the healthy control group. The entire investigation was recorded in a continuous loop review memory on a hard disk and stored on a magneto-optical-disk for off-line analysis.

An optimal acoustic window in the temporal bone was individually sought for the transcranial examination. For easier anatomical orientation on the B-mode scan, the midline and the echogenic structures of the brain stem were displayed with greyscale imaging in the transverse axial plane. Subsequently, imaging in two-axial scanning planes was performed: firstly in the plane through the mesencephalic brainstem, achieved by scanning in the orbitomeatal scanning plane and secondly in the plane through the diencephalon at the level of the thalamus (diencephalic plane) - achieved by angling the transducer $10^{\circ}$ apically [16-18]. Prior to the contrast examination, angle-corrected spectral Doppler measurements in the middle cerebral artery, anterior cerebral artery and posterior cerebral artery on both sides were performed.

Transcranial examination was first performed in four healthy volunteers, in order to test the practical application of CPS in such a set-up, and to obtain information about the distribution and characteristics of the contrast agent SonoVue ${ }^{\mathrm{TM}}$ in the brain parenchyma as reported by the CPS imaging software. In stroke patients, the sonography examiners were blinded to the results of the initial CT or MRI examinations. They were only informed of the diagnosis of an ischaemic stroke and of the neurological symptoms.

\section{Data analysis}

The grey-scale images of the healthy control subjects and of the patient group were compared before and after application of the contrast agent. After the examination, available MR images were used as a reference while defining regions of interest (ROIs) in the most-affected (least perfused) ischaemic areas of the diencephalic or axial insonation plane. Non-affected areas were selected accordingly and served as control conditions. The intensity of the grey-scale signal change was normalised to each subject's individual control and analysed over time. Time-intensity curves were generated for each ROI. Polynominal fits for the resulting plots were calculated for visualisation purposes. In the patient group, an intensity increase of less than $15 \%$ was considered as reduced perfusion. Mean steady state perfusion quotient was calculated by dividing mean intensity during the steady state plateau by basal intensity.

The ultrasound images on the screen, the electronically stored original images and the images after injection of the contrast agent were analysed independently by two investigators (EB and $\mathrm{SH}$ ). 
The third ventricle, the mid-line, the brain stem and the pineal gland served as anatomical landmarks. The homogeneity of the ultrasound images, the enhancement produced by the contrast agent, the possible presence of artefacts and agreement with data from MR imaging were assessed. Calculations of the image and intensity parameters were performed off-line using the commercially available software Data Pro (Noesis S.A., France).

\section{Results}

In all healthy volunteers, adequate cerebral contrast enhancement was achieved. Measurements were carried out in the thalamus and in the MCA territory on both sides and in the frontal lobe ipsilaterally. After application of the contrast agent, acoustic intensity increased in the regions of interest in all of these control subjects. The most homogeneous area of the perfusion was found in the region of the thalamus on both sides. In contrast to our previous study, the MCA territory could be visualised well, not only ipsilaterally, but also on the contralateral side. The distribution of the contrast agent could be recognized on the screen on the entire imaged section of the brain, including the contralateral hemisphere after a few seconds. The mean time to peak intensity was $29 \mathrm{~s}$ in the ipsilateral MCA region and $35 \mathrm{~s}$ in the contralateral MCA region. In absolute values, the difference between the intensity of the ipsilateral and contralateral signals during bolus effect (54.1 dB ipsilaterally, $45.5 \mathrm{~dB}$ contralaterally) was less than that in our previous study, which had been performed without CPS. The triggered registration with pulsing intervals of $500 \mathrm{~ms}$ showed a good distribution of the contrast agent as well. The best visualisation of the contrast-enhanced signal in the capillaries of the brain parenchyma, however, was achieved using triggered images with pulsing intervals of $1000 \mathrm{~ms}$ and a MI of 1.1. Fig. 1 shows exemplary data of typical time-intensity curves at various ROIs in a healthy subject. $15 \mathrm{~s}$ seconds after injection of the contrast agent, a $50 \%$ increase of basal intensity could be observed in the cerebral tissue. The mean steady state perfusion quotient was $275 \%$ ipsilaterally and $245 \%$ contralaterally. The time to peak intensity followed by a steady-state plateau with increased intensity values was 29 s/35 s, respectively.

In stroke patients, after injection of the contrast agent and using triggered registration, a gradual (at intervals of $1000 \mathrm{~ms}$ ), diffuse increase of the echogenicity in the cerebral parenchyma was observed. At the same time, a perfusion deficit in the ischaemic region could be visualised to a satisfying degree on the ipsilateral side in all subjects. Regions of reduced perfusion could be detected, consistent with the affected vascular territory, in the area of the left MCA in 2 patients, in the area of left ACA and MCA in 1 patient, in the area of left MCA and PCA in 1 patient, in the ipsi- and contralateral MCA territory in 1 patient, and in the area of the left MCA, ACA and PCA in 1 patient. In all patients, the increase in intensity of the contrast-enhanced ultrasound signal was greater ipsilaterally, whereas the contralateral perfusion signal was weaker due to greater insonation depth. Additionally, in two patients, the ischaemic lesion was visible not only on the insonation side, but also using insonation from the contralateral temporal side. Continuous registration with a mechanical index of 0.28 was successful in half of the patients (see Fig. 2 and $\mathbf{3}$ and Table $\mathbf{1}$ for exemplary data). Because of a small number of patients involved in this preliminary study, an exact statistical analysis was not possible.

The results of the examination of the stroke patients depended on the examiners' proficiency, which increased with practice. Especially in the first examination period with the new contrast technology, the need for skill in adjusting the position of the transducer during the insonation made the evaluation problematic. A small displacement of the transducer prevents an exact calculation of the time-intensity curves because it changes the position of the "region of interest". In the first two stroke patients of this study, the area of perfusion deficit was determined using contrast-enhanced sonography. The exact perfusion values and time-intensity curves, however, could not be obtained because of the movement of the transducer during the distribution of the contrast agent in the parenchyma.
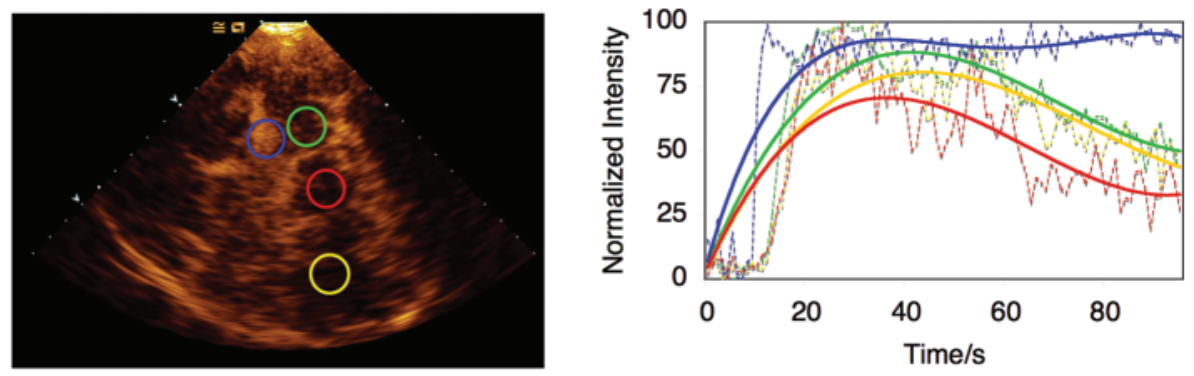

Fig. 1 Contrast-enhanced transcranial B-mode sonography in the axial diencephalic plane in a 23-year-old healthy volunteer after intravenous application of the contrast agent SonoVue (left), and the time intensity curves in the ipsi- and contralateral MCA territories (right), showing the mean intensity values and a good distribution of the contrast agent after $15 \mathrm{~s}$ - not only ipsilaterally, but also on the contralateral side. Triggered registration with a pulsing interval of $1000 \mathrm{~ms}(\mathrm{MI}=1.1)$. Raw data is shown in dotted lines. The trend-lines more clearly depict the perfusion dynamics. (The region of interest marked with a blue circle and a blue line shows higher intensity values than those measured in the neighbouring regions - as it was placed in the area of the left middle cerebral artery.)

Abb. 1 Kontrastverstärkte transkranielle B-Bild-Sonographie in der axialen dienzephalen Ebene bei einem 23 Jahre alten gesunden Probanden nach intravenöser Applikation des Kontrastmittels SonoVue (links) und die Zeit-Intensitäts-Kurven in ipsi- und kontralateralem Stromgebiet der A. cerebri media (rechts) mit der Darstellung der Intensitätswerte und der guten Verteilung des Kontrastmittels 15 Sekunden nach der Applikation nicht nur ipsilateral, sondern auch in der kontralateralen Hemisphäre. Getriggerte Ableitung mit einem Zeitintervall von 1000 ms (MI = 1,1).

Die Rohdaten sind mit der gepunkteten Linie dargestellt. Die Trendlinien stellen besser die Perfusionsdynamik dar. (Die blaue markierte Region zeigt höhere Intensitätswerte als die Nachbarregionen - bei Platzierung der Messpunkte über der A. cerebri media links). 


\begin{tabular}{|c|c|c|c|c|}
\hline & \multicolumn{2}{|c|}{ Healthy control } & \multicolumn{2}{|l|}{ Patients $^{1}$} \\
\hline & Ipsilateral & $\begin{array}{l}\text { Contra- } \\
\text { lateral }\end{array}$ & $\begin{array}{l}\text { Perfusion } \\
\text { deficit area }\end{array}$ & $\begin{array}{l}\text { Non-af- } \\
\text { fected } \\
\text { region }\end{array}$ \\
\hline $\begin{array}{l}\text { Time between the application of the contrast agent } \\
\text { and its first appearance in the tissue }(\mathrm{s})^{2}\end{array}$ & 15 & 18 & 19 & 23 \\
\hline Time to peak intensity (s) & 29 & 35 & 37 & 32 \\
\hline $\begin{array}{l}\text { Mean intensity of the grey scale image before appear- } \\
\text { ance of the contrast agent }(\mathrm{dB})\end{array}$ & 19.7 & 18.6 & 34.8 & 37.9 \\
\hline Mean intensity during the bolus effect (dB) & 54.1 & 45.5 & 37.0 & 56.1 \\
\hline Mean bolus perfusion quotient $(\%)^{3}$ & 275 & 245 & 106 & 148 \\
\hline
\end{tabular}

Table 1 Mean perfusion values based on the data of the subjects shown in Fig. 1-3. Triggered acquisition (MI 1.1). Intensities are given in absolute (non-normalised) values

In all patients, the size and localisation of the perfusion deficit on the contrast-enhanced ultrasound images corresponded with the ischaemic regions as seen after the sonographic examination during subsequent MR imaging (Fig. 2 D, 3E). The contrast-enhanced study was completed by colour-coded duplex examination of the intracranial arteries and veins (Fig. $\mathbf{3} \mathbf{H}$ ). Sufficient enhancement of the colour-coded signal was present for up to 20-30 minutes. The contrast agent SonoVue ${ }^{\mathrm{TM}}$ was well tolerated in both groups. No side effects could be observed during the injection of the agent.

\section{Discussion}

Contrast media were initially developed to enhance the Doppler signal detected in the arteries and veins. The better the ultrasound equipment has become, however, the less frequent has been the need for contrast enhancement of the backscattered signals. Modern, high-end, colour-coded duplex ultrasound systems are usually able to detect a sufficiently viable Doppler signal even without the use of contrast agents. Contrast media are therefore nowadays mostly used to increase diagnostic certainty, through visualisation of slow blood flow velocity - especially in occlusive vascular disease. The development of $2^{\text {nd }}$ generation contrast agents opened up new technical perspectives for imaging slow blood flow velocity in the capillaries of certain tissues, as shown for organs like liver and heart [19-22]. In contrast, imaging of cerebral perfusion is still in the experimental stage [23]. Recently, several imaging techniques such as stimulated acoustic emission (SAE) technique, transit-time analysis, replenishment analysis, contrast burst depletion imaging, parametric imaging, etc., were developed for imaging tissue perfusion [24, 25]. Although all these techniques showed promising results, neither of them have so far found their way into routine cerebral diagnostics. In 2004, Seidel reported on imaging of cerebral perfusion deficit in 23 stroke patients, demonstrating a significant correlation of amplitude decrease using contrast agent bolus injection (BHI) with the definite area of infarction shown by follow-up CCT [26]. There are still methodological problems in the evaluation, however, and furthermore, a comparison of sonographic results with studies using perfusion CCT or MRI is not possible, because only one insonation plane and not the whole volume of ischaemic brain tissue can be examined.
The higher mechanical index needed to penetrate the temporal bone window is one of the key restraints in transcranial sonography. Our study in a group of patients with decompressive craniectomy after malignant cerebral ischaemia or haemorrhage, in which a lower mechanical index was used, demonstrated the capability of the contrast agent SonoVue ${ }^{\mathrm{TM}}$ to image cerebral perfusion and the less perfused areas of the brain. The next step lay with the manufacturers of ultrasound systems to overcome the technical "obstacle" posed by the human anatomy, which has in part been accomplished by CPS imaging as shown in this study. The short duration of the study and the limited number of patients examined do not allow a statistical analysis. This report therefore mainly aims to stimulate discussion in this diagnostic field and to blaze a trail for this method in clinical routine diagnostics. Using CPS imaging technology in young, healthy volunteers with a good insonation window on the temporal bone, the distribution of the contrast agent was easier to detect than in our previous study. The contrast-enhanced signal could also be well recognised in the contralateral hemisphere right up to the crown of the skull, because the depth-dependent attenuation of the backscattered ultrasound waves was less pronounced (Fig. $\mathbf{3} \mathbf{A}$ ).

In the group of older stroke patients, the distribution of the contrast agent and the detection of the less perfused areas were possible not only ipsilaterally but even contralaterally in about $30 \%$ of the patients (Fig. 3C).

Our attempt to use CPS imaging for the visualisation of cerebral perfusion using continuous insonation with a low mechanical in$\operatorname{dex}(\mathrm{MI}=0.28)$ was less satisfactory as compared to the triggered registration. This approach proved to be less effective because a relatively small number of contrast agent microbubbles could be detected in the B-mode image. Inspired by the cardiac contrast studies, we decided to insonate intermittently in a triggered approach using single frames at specific time intervals. Increasing the pulsing intervals by $500 \mathrm{~ms}, 1000 \mathrm{~ms}$ and $2000 \mathrm{~ms}$, we found the most suitable contrast enhancement as well as image resolution to be obtained at intervals of $1000 \mathrm{~ms}$.

CPS imaging also allows for calculation of time-intensity curves integrated into the software, so that the signal intensity in the ROI can be immediately obtained by the ultrasound system or calculated later off-line. Most other reports on cerebral perfusion 

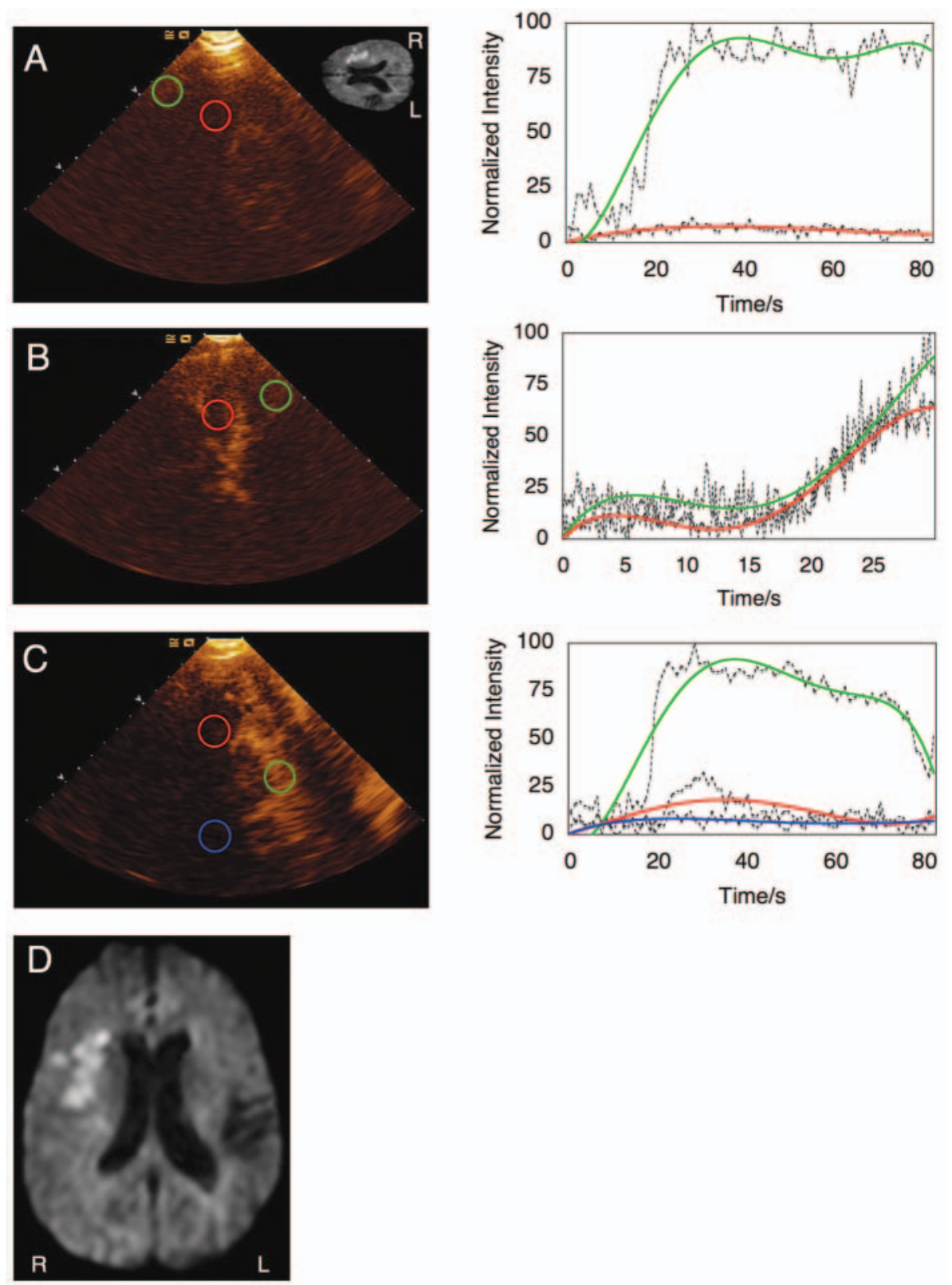

Fig. 2 Contrast-enhanced transcranial B-mode sonography images in the axial diencephalic plane and time-intensity curves in a 62-year-old man with a recent infarction in the right MCA territory and an old infarction in the left MCA territory. A Right temporal insonation showing a perfusion deficit in the right MCA area, using a triggered registration with a pulsing interval of $1000 \mathrm{~ms}(\mathrm{MI}=1.1)$. B above, using a continuous registration $(\mathrm{MI}=0.28)$. C Left temporal insonation showing a perfusion deficit in the old left MCA infarct area (red line), and the recent perfusion deficit on the contralateral side (blue line). Triggered registration with a pulsing interval of $1000 \mathrm{~ms}(\mathrm{MI}=1.1)$. D MR imaging shows old left temporal infarction and recent right temporal infarction (FLAIR sequence).

Raw data is shown in dotted lines. The trend-lines more clearly depict the perfusion dynamics. The region of the ipsilateral perfusion deficit is hypoechoic on all three images and is marked by a red circle. Note the acoustic shadowing behind the old infarction zone which can lead to misinterpretation (C, see text).

Abb. 2 Kontrastverstärkte transkranielle B-Bild-Sonographie in der axialen dienzephalen Ebene und Zeit-Intensitäts-Kurven bei einem 62 Jahre alten Patienten mit einer frischen Ischämie im Stromgebiet der rechten A. cerebri media und einer alten Ischämie im Stromgebiet der linken A. cerebri media. A Darstellung eines Perfusionsdefizits im Stromgebiet der rechten A. cerebri media mithilfe der transtemporalen Beschallung rechts bei einer getriggerten Ableitung (Zeitintervall $1000 \mathrm{~ms}, \mathbf{M I}=1,1)$. B wie in Abb. A, kontinuierliche Ableitung $(\mathrm{MI}=0,28)$. C Darstellung eines zerebralen Perfusionsdefizits bei einer alten Ischämie im Stromgebiet der linken A. cerebri media (rote Linie) und einer frischen Ischämie im Stromgebiet der rechten A. cerebri media kontralateral (blaue Linie) bei transtemporaler Beschallung links. Getriggerte Ableitung (Zeitintervall $1000 \mathrm{~ms}, \mathrm{MI}$ = 1,1). D Magnetresonanztomographische Darstellung des alten Infarktes im Stromgebiet der A. cerebri media links und des frischen Infarktes im Stromgebiet der A. cerebri media rechts (FLAIR-Sequenz).

Die Rohdaten sind mit der gepunkteten Linie dargestellt. Die Trendlinien stellen besser die Perfusionsdynamik dar. Das Gebiet des ipsilateralen Perfusionsdefizits ist echoarm auf allen drei Abbildungen und ist mit einem roten Kreis gekennzeichnet. Die Schallauslöschung hinter der ischämischen Zone (Abb. C) kann zu einer Fehlbeurteilung führen. 

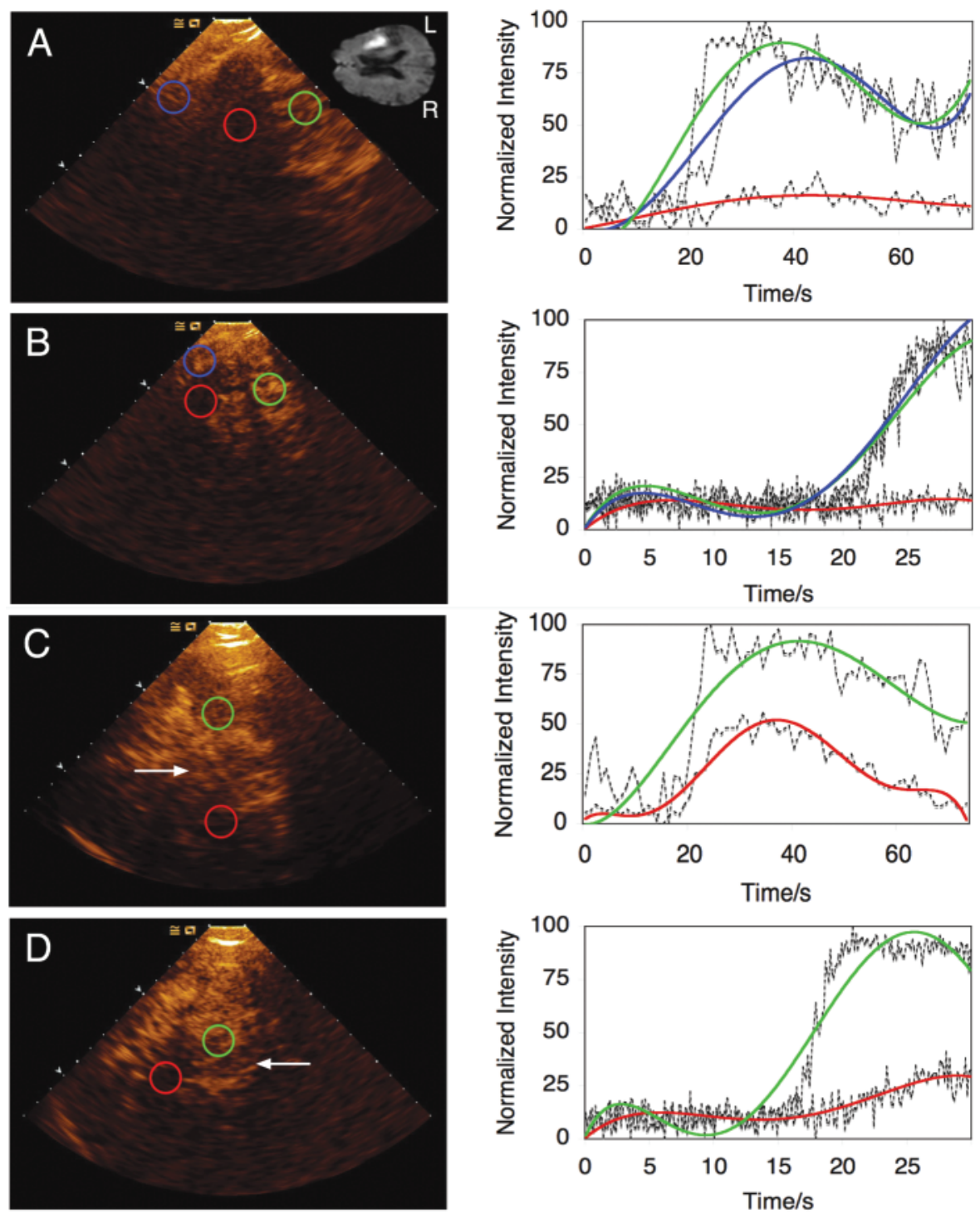

Fig. 3 Contrast-enhanced transcranial B-mode sonography in the axial diencephalic plane and time intensity curves in a 64 years old man with a recent infarction in the left MCA territory using an ipsilateral and contralateral transtemporal approach. A Left temporal (ipsilateral to lesion) insonation showing a perfusion deficit in the left MCA area using a triggered registration with a pulsing interval of $1000 \mathrm{~ms}$ (MI=1.1). (Figure $3 \mathrm{~F}$ shows the original sonographic perfusion image with a schematic drawing.) B above, using a continuous registration (MI=0.28). C Right temporal (contralateral to lesion) insonation showing a perfusion deficit in the left MCA territory using a triggered registration with a pulsing interval of $1000 \mathrm{~ms}(\mathrm{Ml}=1.1)$. (Figure 3G shows the original sonographic perfusion image with a schematic drawing.) D above, using a continuous registration $(\mathrm{Ml}=0.28)$.

Abb. 3 Kontrastverstärkte transkranielle B-Bild Sonographie in der axialen dienzephalen Ebene und Zeit-Intensitäts-Kurven bei einem 64 Jahre alten Patienten mit einer frischen Ischämie im Stromgebiet der linken A.cerebri media bei ipsi- und kontralateraler transtemporaler Beschallung. A Darstellung eines Perfusionsdefizits im Stromgebiet der linken A.cerebri media mithilfe der transtemporalen Beschallung links (ipsilateral in Bezug auf die Läsion) bei einer getriggerten Ableitung (Zeitintervall $1000 \mathrm{~ms}$, MI = 1,1). (Die Abb. 3f zeigt die sonographische Darstellung mit schematischer Zeichnung der ischämischen Läsion.) B wie in der Abb. A, kontinuierliche Ableitung (Ml=0.28). C Darstellung eines Perfusionsdefizits im Stromgebiet der linken A.cerebri media mithilfe der transtemporalen Beschallung rechts (kontralateral in Bezug auf die Läsion) bei einer getriggerten Ableitung (Zeitintervall 1000 ms, MI = 1,1). (Die Abb. 3G zeigt die sonographische Darstellung mit schematischer Zeichnung der ischämischen Läsion.) D wie in der Abb. C, kontinuierliche Ableitung (MI=0.28).

published up to now involved either a complicated calculation procedure, or were difficult to use in routine diagnostics.

Pitfalls in the assessment of intensities in ischaemic regions occur if the region of interest selected is over a vessel (e.g. the branch of a middle cerebral artery). Thus, in one patient in our study with middle cerebral artery infarction, the flow signal of the artery also erroneously entered into our calculation, and therefore no perfusion deficit was measured. It was only with the control measurement taken in another region of interest that this mistake in calculation became clear.

Moreover, in evaluating the intensities of smaller lesions, mistakes can occur due to a limited spatial resolution, if the ROI also covers parts of a non-affected brain region.

Another source of potential error occurs if a second (contralateral) ischaemic area is located in the direction of the ultrasound 

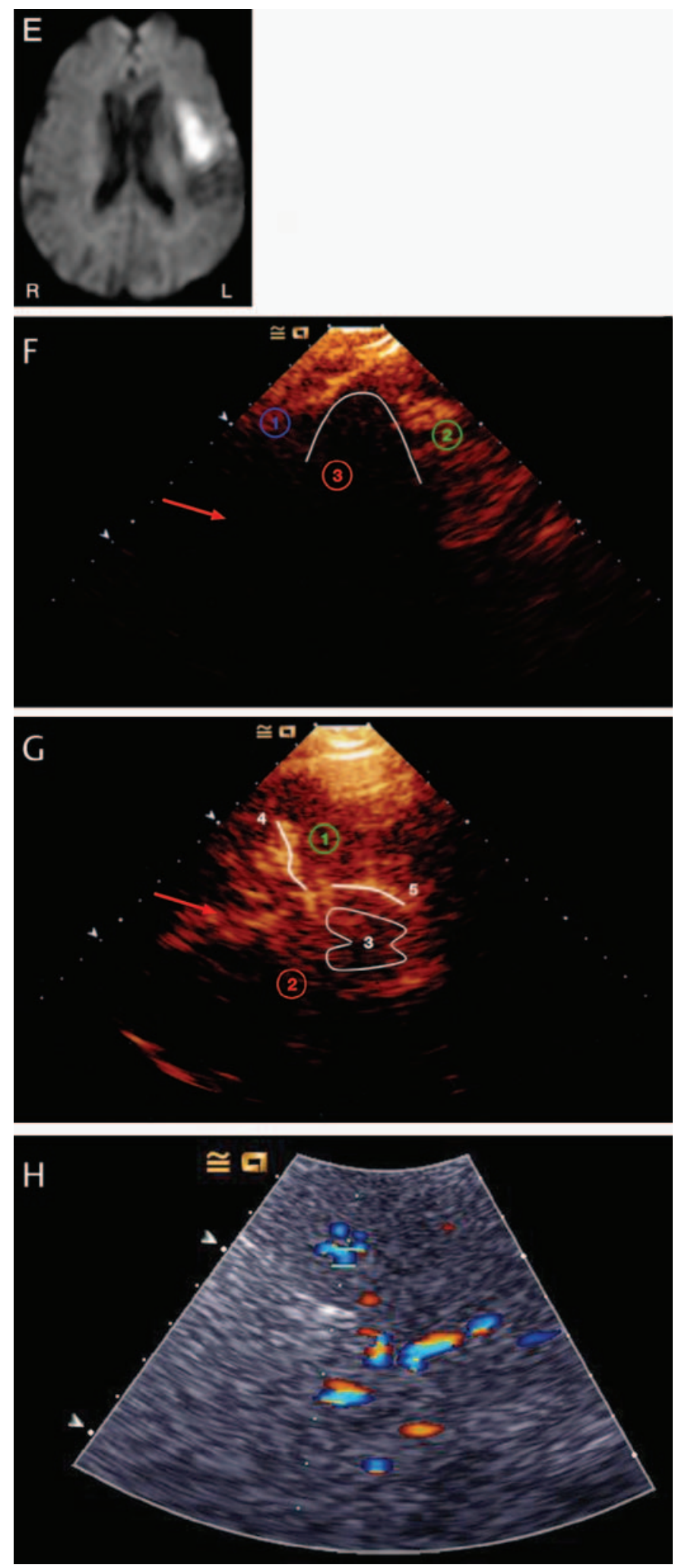

beam behind the infarction zone. This ischaemic area can be overlooked due to a lateral acoustic shadowing caused by the tangential incidence of the acoustic beam over the borderline of the proximal infarction zone (Fig. 2 C) [18].

Careful adjustment of the position of the transducer during the insonation is also critical, and errors here render the evaluation problematic since slight shifts in transducer placement can
Fig. 3 E MR imaging shows left recent infarction and underlying hypodense areas hinting at an additionally present older infarction in the same vascular territory. (FLAIR sequence). F Original sonographic perfusion image and schematic drawing of the Figure 3a obtained 28 seconds after the bolus injection of the contrast agent Sonovue, examining in the left midthalamic ipsilateral insonation plane and using the left (ipsilateral) temporal approach: good distribution of the contrast medium in the frontotemporal (circle 1) and occipitotemporal regions (circle 2), perfusion deficit in the middle cerebral artery territory left (circle 3). G Original sonographic perfusion image and schematic drawing of the Figure $3 c$ obtained 33 seconds after the bolus injection of the contrast agent Sonovue, examining in the midthalamic insonation plane, and using the right temporal approach, shows a good distribution of the contrast medium in the right hemisphere (circle 1 ) and a perfusion deficit contralaterally (circle 2). 3 = brainstem, $4=$ right middle cerebral artery, $5=P 2$ segment of the right posterior cerebral artery. $\mathbf{H}$ Color-coded image of the arteries of the Circle of Willis after the evaluation of the cerebral perfusion deficit. The basal cerebral arteries can be seen in the midthalamic insonation plane because of the contrast enhanced flow; however, only diagonal sections of the vessels (not a continuous course) are visible. The sample volume for the recording of the Doppler spectrum is placed in the left middle cerebral artery.

Raw data is shown in dotted lines. The trendlines more clearly depict the perfusion dynamics. The region of the perfusion deficit (marked with a red circle) can be recognized using both triggered and continuous registration by temporal insonation, ipsi- and contralaterally. Arrow: midline. Abb. 3 E Kernspintomographische Darstellung eines frischen Infarktes im Stromgebiet der A.cerebri media links und einer hypodensen Region, die für eine zusätzliche alte Ischämie im gleichen Stromgebiet spricht. (FLAIR Sequenz). F Sonographische Darstellung des Perfusionsdefizits ipsilateral mit schematischer Zeichnung der ischämischen Läsion der Abb. 3a, aufgenommen 28 Sekunden nach Bolusapplikation des Kontrastmittels SonoVue. Untersuchung in der dienzephalen Beschallungsebene bei transtemporaler Beschallung links. Gute Ausbreitung des Kontrastmittels in den frontotemporalen (Kreis 1) und okzipitotemporalen (Kreis 2) Regionen, Perfusionsdefizit im Mediastromgebiet links (Kreis 3). G Sonographische Darstellung des Perfusionsdefizits kontralateral mit schematischer Zeichnung der ischämischen Läsion der Abb. 3c, aufgenommen 33 Sekunden nach Bolusapplikation des Kontrastmittels SonoVue. Untersuchung in der dienzephalen Beschallungsebene bei transtemporaler Beschallung rechts. Gute Ausbreitung des Kontrastmittels ipsilateral (Kreis 1), Perfusionsdefizit kontralateral (Kreis 2). 3 = Hirnstamm, 4 = A.cerebri media rechts, $5=$ P2 Segment der A.cerebri posterior rechts. H Farbkodierte Darstellung der Arterien des Circulus arteriosus Willisii nach der Untersuchung der zerebralen Perfusion. Die basalen zerebralen Arterien sind auch in der dienzephalen Ebene aufgrund der Kontrastverstärkung gut sichtbar. Bedingt durch die Schallebene ist der Verlauf der Arterien nicht kontinuierlich, sondern nur in diagonalen Schnitten darstellbar. Das Meßvolumen für die Ableitung der Dopplerpulskurve ist platziert in der linken A. cerebri media.

Die Rohdaten sind mit der gepunkteten Linie dargestellt, die Trendlinien stellen besser die Perfusionsdynamik dar. Das Gebiet des Perfusionsdefizits (markiert mit einem roten Kreis) ist sichtbar sowohl bei einer getriggerten, als auch bei einer kontinuierlichen Registrierung, bei transtemporaler Beschallung ipsi- und kontralateral. Pfeil: Mittellinie.

make exact calculation of perfusion values and time-intensity curves impossible. A practical approach which we found useful was to initially screen by scanning with the first portion $(2.5 \mathrm{ml})$ of the contrast agent in all axial imaging planes. The second portion of the contrast agent is used for exact calculation in the detected hypoperfused region. With this approach, a lesion not localised in the axial plane, but more subcortically, is not likely to be overlooked. 
In conclusion, the present preliminary study shows that CPS imaging is a suitable tool for the bedside, real-time ultrasonographic evaluation of cerebral perfusion. Based on our prior experience without this imaging software, we conclude that the distribution of the contrast agent in the cerebral parenchyma and the deficit in the less perfused areas can be detected more easily. Further studies should be carried out with a greater number of patients with cerebral ischaemia to optimize the transcranial setting and also to provide data for a statistical assessment of the value of this method.

\section{Acknowledgments}

The authors thank Dr. C. Greis and W. Randhan (Bracco/Altana Pharma) for support and for supplying the ultrasound contrast agent (SonoVue ${ }^{\mathrm{TM}}$ ), Dr.-Ing. S. Werner and S. Williams (Siemens Medical Solution) for technical and software assistance and Mrs. C. Crozier for language editing of the manuscript.

\section{References}

${ }^{1}$ Droste DW, Llull JB, Pezzoli C et al. SonoVueTM (BR1), a new long-acting echocontrast agent, improves transcranial colour-coded duplex ultrasonic imaging. Cerebrovasc Dis 2002; 14: 27-32

${ }^{2}$ Nabavi DG, Droste DW, Kemény V et al. Potential and limitations of echocontrast-enhanced ultrasonography in acute stroke patients. Stroke 1998; 29: 949 - 954

3 Porter TR, Xie F. Transient myocardial contrast after exposure to diagnostic ultrasound pressures with minute doses of intravenously injected microbubbles: Demonstration and potential mechanisms. Circulation 1995; 92: $2391-2395$

${ }^{4}$ Postert T, Muhs A, Meves S et al. Transient response harmonic imaging: An ultrasound technique related to brain perfusion. Stroke 1998; 29: 1901 - 1907

${ }^{5}$ Seidel G, Claassen L, Meyer K et al. Evaluation of blood flow in the cerebral microcirculation: Analysis of the refill kinetics during contrast agent infusion. Ultrasound Med Biol 2001; 27: 1059-1064

${ }^{6}$ Wiesmann M, Seidel G. Ultrasound perfusion imaging of the human brain. Stroke 2000; 31: $2421-2425$

${ }^{7}$ Meairs S, Daffertshofer M, Neff W et al. Pulse-inversion contrast harmonic imaging: ultrasonographic assessment of cerebral perfusion. Lancet 2000; 355: 550-551

8 Seidel G, Albers T, Meyer K et al. Perfusion harmonic imaging in acute middle cerebral artery infarction. Ultrasound Med Biol 2003; 29: $1245-1251$

${ }^{9}$ Martina AD, Meyer-Wiethe K, Alleman E et al. Ultrasound contrast agents for brain perfusion imaging and ischemic stroke therapy. J Neuroimaging $2005 ; 15: 217-232$
${ }^{10}$ Keir SL, Wardlaw JM. Systematic review of diffusion and perfusion imaging in acute stroke. Stroke 2000; 31: $2723-2731$

${ }^{11}$ Harrer JU, Klötzsch C, Stracke CP et al. Cerebral perfusion sonography in comparison with perfusion MRT: a study with healthy volunteers. Ultraschall in Med 2004; 25: $263-269$

${ }^{12}$ Shiogai T, Takayasu N, Mizuno T et al. Comparison of transcranial brain tissue perfusion images between ultraharmonic, second harmonic, and power harmonic imaging. Stroke 2004; 35: 687-693

${ }^{13}$ Bartels E, Bittermann HJ. Transcranial contrast imaging of cerebral perfusion in stroke patients following decompressive craniectomy. Ultraschall in Med 2004; 25: 206-213

${ }^{14}$ Vannan MA, Kuersten B. Imaging techniques for myocardial contrast echocardiography. Eur J Echocardiography 2000; 1: 224-226

${ }^{15}$ Eyding J, Wilkening W, Postert T. Brain perfusion and ultrasound imaging techniques. In: Bartels E (Hrsg). Update in Cerebral Hemodynamics and NeurosonologyEuropean Journal of Ultrasound, 2002: 16: $91-104$

${ }^{16}$ Bartels E, Flügel KA. Quantitative measurements of blood flow velocity in basal cerebral arteries with transcranial color-Doppler imaging. J Neuroimag 1994; 4: 77-81

${ }^{17}$ Bartels E. Transkranielle farbkodierte Duplexsonographie: Möglichkeiten und Grenzen der Methode im Vergleich mit der konventionellen transkraniellen Dopplersonographie. Ultraschall in Med 1992; 13: $59-66$

${ }^{18}$ Bartels E. Color-Coded Duplex Ultrasonography of the Cerebral Vessels/Atlas and Manual; Farbduplexsonographie der hirnversorgenden Gefässe/Atlas und Handbuch. Stuttgart: Schattauer, 1999: p.88, pp. $189-195$

19 Becker D. Contrast enhanced ultrasound in the liver using low mechanical index - what is a difference? Ultraschall in Med 2002; 23: 397-402

${ }^{20}$ Bernatik T, Becker D, Neureiter D et al. Detection of liver metastases comparison of contrast-enhanced ultrasound using first versus second generation contrast agents. Ultraschall in Med 2003; 24: 175-179

${ }^{21}$ Albrecht T et al. EFSUMB Study Group: Guidelines for the use of contrast agents in ultrasound - January 2004. Ultraschall in Med 2004; 25: $249-256$

${ }^{22}$ Konopke R, Kersting S, Saeger HD et al. Detection of liver lesions by contrast-enhanced ultrasound - Comparison to intraoperative findings. Ultraschall in Med 2005; 26: $107-113$

${ }^{23}$ Stolz E, Allendörfer J, Jauss M et al. Sonographic harmonic grey scale imaging of brain perfusion: Scope of a new method demonstrated in selected cases. Ultraschall in Med 2002; 23: 320-324

${ }^{24}$ Eyding J, Wilkening W, Krogias C et al. Validation of the depletion kinetic in semiquantitative ultrasonograpic cerebral perfusion imaging using 2 different techniques of data acquisition. J Ultrasound Med 2004; 23: 1035-1040

${ }^{25}$ Eyding J, Wilkening W, Reckhardt M et al. Reliability of semiquantitative ultrasonic perfusion of the brain. J Neuroimaging 2004; 14 : 143 149

${ }^{26}$ Seidel G, Meyer-Wiethe K, Berdien G et al. Ultrasound perfusion imaging in acute middle cerebral artery infarction predicts outcome. Stroke 2004; 35: 1107 - 1111 